\title{
AUSTRALIAN, MELANESIAN AND MICRONESIAN ACROPSILUS MIK (DIPTERA: DOLICHOPODIDAE)
}

\begin{abstract}
Bickel, D. J, 1998. Australian, Melanesian, and Micronesian Acropsilus Mik (Diptera: Dolichopodidae).- Tijdschrift voor Entomologie 141: 1-17, figs. 1-21. [ISSN 0040-7496]. Published 30 November 1998.

The Australian, Melanesian, and Micronesian species of the genus Acropsilus Mik (Diptera: Dolichopodidae) are revised, and comprise eleven species: Acropsilus protractus Robinson (Solomon Islands, New Guinea, trop. Australia), and ten newly described species: A. albitibia (trop. Australia, New Guinea, Solomon Islands, Vanuatu), A. boharti (Irian Jaya, Solomon Islands) A. colmani ( Papua New Guinea), .A. kuranda (Queensland), A. malaita (Solomon Islands), A.. maprik (Papua New Guinea), A. nigricornis ( Solomon Islands, New Guinea, Queensland), A.. putosa (Papua New Guinea), A. toma (Papua New Guinea), and A. udot (Micronesia: Truk). Some species are widely distributed in the Australasian tropics.

Acropsilus is known only from the Old World, and is particularly rich and often abundant in moist tropical habitats. The entire genus is reviewed and redefined, and its phylogenetic position is discussed. Acropsilus is close to the Oriental genus Griphomyia and both genera are tentatively referred to the Peloropeodinae, a subfamily which requires redefinition.

D.J. Bickel, Entomology Section, Australian Museum, 6 College Street, Sydney, Nsw 2000 Australia. E-mail: danb@amsg.austmus.oz.au

Key words. - Diptera, Dolichopodidae, Acropsilus, Australia, Melanesia, Micronesia.
\end{abstract}

The genus Acropsilus Mik comprises small-sized dolichopodids. Although this genus initially appears to be rather nondescript, males of many species are easily recognised by their elongate ivory-white cerci, which project out from a pedunculate hypopygium. Closer examination reveals a number of uniquely derived features which define the genus, and it has not been readily placed in any of the traditional dolichopodid subfamilies.

Previously six species had been described from widely separated locales in Europe, Tadzhikistan, West Africa, the Seychelles, Sumatra and the Solomon Islands. However, mass trapping methods, particularly malaise and water traps, reveal the genus to be abundant and rich in the Indo-Malayan and Australasian wet tropics. This paper considers the fauna of Australia, Melanesia and Micronesia, and treats eleven species, ten of which are newly described. Two species, Acropsilus protractus and A. albitibia are widespread throughout Melanesia and northern Australia (figs. 20, 21).

\section{Materials AND ACKNOWLEDGeMENTS}

This study is based on material from major world collections. Institutional abbreviations for material cited follows, and I thank the respective curators and support staff for the loan of specimens.

AMS Australian Museum, Sydney - M. Moulds;

ANIC Australian National Insect Collection, CsIro, Canberra - P. Cranston;

врвм Bernice P. Bishop Museum, Honolulu - N. Evenhuis;

CAS California Academy of Sciences, San Francisco - P. Arnaud;

CMNH Carnegie Museum of Natural History, Pittsburgh - C. Young;

CNC Biosystematics Research Institute, Agriculture Canada - J. Cumming;

Nmwc National Museum of Wales, Cardiff. - J. Deeming;

UsNM National Museum of Natural History, Smithsonian Institution, Washington, D. C - F. C. Thompson;

zMUC Zoological Museum, University of Copenhagen - V. Michelsen.

S. Bullock drew the genitalic figures. C. E. Dyte provided notes and specimens. P. Grootaert provided valuable comments on an early draft of the manuscript. This research was supported by Australian Biological Resources Study (A.B.R.s.) grants 85/0921 and $87 / 5905$. 


\section{Methods}

Drawings of genitalia were made with a camera lucida attached to a compound microscope. The left lateral view of the hypopygium or male genital capsule is illustrated for most species. In describing the hypopygium, 'dorsal' and 'ventral' refer to morphological position prior to genitalic rotation and flexion. Thus, in figures showing a lateral view of the hypopygium, the top of the page is morphologically ventral, while the bottom is dorsal. Morphological terminology follows McAlpine (1981) and Cumming et al. (1995). Common features are listed in the introductory descriptions and are not repeated in species descriptions unless needing clarification. Measurements are in millimeters and were made on representative dry specimens. Body length is measured from the base of the antennae to the tip of the seventh abdominal segment. Wing length is the perpendicular distance to the apex from an imaginary extension of the humeral crossvein; wing width is measured from the junction of $R_{1}$ with the costa to the opposite side of the wing, perpendicular to the wing's long axis. The $\mathrm{CuAx}$ ratio is the length of the $\mathrm{m}$-cu crossvein/distal section $\mathrm{CuA}$. The position of features on elongate structures such as leg segments are given as a fraction of the total length, starting from the base. The relative lengths of the podomeres should be regarded as representative ratios and not measurements. The ratios for each leg are given in the following formula and punctuation: trochanter + femur; tibia; tarsomere 1/ 2/ 3/ $4 / 5$.

The following abbreviations and terms are used: MSSC - Male secondary sexual character(s), the nongenitalic characters found only on the male body; I, II, III: pro- , meso-, metathoracic legs; C, coxa; T, tibia; F, femur; ac, acrostichal setae; ad, anterodorsal; av, anteroventral; dc, dorsocentral setae; dv, dorsoventral; hm, postpronotal setae; np, notopleural setae; pa, postalar setae; pd, posterodorsal; pm, presutural supra-alar setae; pv, posteroventral; sa, postsutural supra-alar setae; sr, presutural intra-alar setae; t, tarsus; $\mathrm{t}_{1-5}$, tarsomeres 1 to 5 .

\section{SySTEMATIC PART}

\section{Genus Acropsilus Mik}

Acropsilus Mik (1878: 6). Type species: Chrysotus niger Loew 1869: 298, monotypy.

\section{Description}

Male. - Body length ranges from $1.0-2.3 \mathrm{~mm}$, but most species about 1.3-1.6.

Head. - Dorsal postcranium flat to slightly concave; male eyes distinctly separated by face and clypeus; eye facets enlarged anteriorly and ventrally; clypeus usually with four setae: pair midcentral shorter setae, and pair of stronger distal setae (as in fig. 15); strong verticals and strong diverging ocellars present; postverticals represented by $4-5$ short setae, continuation of postorbitals; first flagellomere variably covered in microtrichia; arista apical, and varies from arising on entire outer curvature of first flagellomere (fig. 15) to arising within distinct indentation on the outer curvature (fig. 4); arista with tiny pubescence, and longer than head height; proboscis (fig. 18) with 6 geminate pseudotracheae; epipharyngeal armature with 2 prongs, and dorsal projection with is weakly sclerotised, and adjacent to which are three thorn-like setae.

Thorax. - Usually rather short, and ratio of length/ width about 1.3 (fig. 17); proepisternum with some short setae near posterior margin, and strong seta just dorsad of CI; posterior slope of mesonotum slightly flattened but not depressed; ac absent; $5 \mathrm{dc}$ present, comprising 4 stronger posterior $\mathrm{dc}$ which decrease in size anteriorly, and with additional very weak dc anteriormost, on anterior slope of thorax; $1 \mathrm{pa}, 2 \mathrm{sa}$, anterior much shorter than posterior, $2 \mathrm{sr}, 2 \mathrm{npl}, 1 \mathrm{hm}$, $1 \mathrm{pm}$ present; posterior mesonotum with distinct transverse fold just anteriad of scutellum; median scutellar seta strong, lateral present as weak tiny hair; postscutellum with distinct median longitudinal mound.

Legs. - Mostly yellow; CI and CII with short pale anterior hairs; CII and CIII each with short lateral seta; leg I usually without distinctive setation; FII without distinct true subapical anterior seta, although sometimes some subapical setae many appear slightly stronger; FII with subapical pv seta; TII with strong ad-pd pair at $1 / 4$, strong ad at $3 / 5$, and with strong ventral apical, and with coronet of short setae; FIII without subapical anterior seta, but with weak subapical pv seta; TIII with short ad-pd pair at $1 / 4$, and often with dorsal setae on distal half; male IIIt ${ }_{1}$ sometimes somewhat swollen with ventral row of hairs (MSSC).

Wing (fig. 16). - Membrane hyaline; $\mathrm{R}_{2+3}$ ends in anterior margin at $5 / 6 ; \mathrm{R}_{4+5}$, just anterior to apex; $\mathrm{R}_{4+5}$ and $M$ subparallel; $M$ without flexion or "bosse alaire"; anal vein absent; anal angle weak; $\mathrm{CuAx}$ ratio near 0.3 .

Abdomen. - Usually dark brown; tergal setae not strongly developed; male tergum 1 wide (fig. 17), and distinctly wider than thorax, especially noticeable in dried specimens; hypopygium pedunculate (fig. 1); segment 7 prolonged with distinct elongated tergum and sternum separated by membrane; sternum 8 with distinctive inverted Y-shaped carina ; hypopygial foramen left basolateral; hypandrium and aedeagus both short and emerging at angle near base of epandrium; hypandrium broad and apically upcurved, 
and basally fused with epandrium; aedeagus rather short and slightly curved, and often with notched phallus; ventral margin of epandrium with 2 epandrial setae; epandrial lobe raised from ventral margin and externally overlapping digitiform surstylar arms; subepandrial sclerite well-developed, curved and resting between cerci, and often with group of strongly pedunculate distal setae; cercus usually white-ivory coloured and subtriangular, and bearing pale setae.

Female. - Similar to male except lacking MSSC and as noted: face and clypeus more widely separated, and facets of uniform size; clypeus always with 4 setae; in species where male first flagellomere deeply incised, female less incised; IIIt $t_{1}$ unmodified; female tergum 1 not noticeably wide; oviscapt (figs 3, 4) divided into two hemitergites, each with crest of four spine-like setae, and bearing elongate digitiform process and stalked group of pedunculate setae.

\section{General remarks}

Acropsilus is a distinctive dolichopodid genus known only from the Old World. Based on the species treated below and descriptions, the genus has the following set of diagnostic characters: clypeus of females and most males with four projecting setae: pair midcentral shorter setae, and pair of stronger distal setae; arista apical; posterior slope of mesonotum slightly flattened but not depressed; ac absent; 5 dc present; posterior mesonotum with distinct transverse fold just anteriad of scutellum; $\mathrm{R}_{4+5}$ and $\mathrm{M}$ subparallel; male tergum 1 wide, and distinctly wider than thorax; hypopygium pedunculate: segment 7 elongate; sternum 8 with distinctive inverted Y-shaped carina; hypandrium basally fused to epandrium; epandrial lobe raised from ventral margin and externally overlapping digitiform surstylar arms; subepandrial sclerite welldeveloped, curved and resting between cerci, and often with pedunculate distal setae; cercus usually white-ivory coloured and prominent; oviscapt divided into two hemitergites, each with a crest of 4 spinelike setae, and bearing elongate digitiform process and stalked group of pedunculate setae.

Acropsilus is particularly rich in the moist Afrotropical, Oriental and tropical Australasian regions, where many species undoubtedly await description. However, species are also known from western Europe and even at elevations of $1300 \mathrm{~m}$ in Tadzhikistan. Specimens are frequently taken in malaise and water (pan) traps, especially in tropical lowlands. In the Ivory Coast, Coutourier (1978) noted that A. eburneensis was abundant throughout the forest-savannah mosaic during the rainy season, but confined to gallery forests during the dry season. Similarly, in northern Australia, Acropsilus species are abundant and widespread during and after monsoonal rains, but are confined to permanent water during the drier periods.
Males of many species have bright ivory-white cerci, which may function in sexual signalling. Here it should be noted that Acropsilus albitibia has ivorywhite tibiae I and II (MSSC), which possibly augment the function of the cerci. However, P. Grootaert (pers. comm.) notes that many undescribed species from Thailand have short cerci and greatly enlarged hypopygia.

In the Australasian tropics, Acropsilus protractus and A. albitibia are particularly widespread throughout Melanesia and northern Australia (figs. 20, 21). Three species occur in Australia, where the genus is confined to the monsoonal tropics and the Queensland coast south to the Tropic of Capricorn. Acropsilus is known as far east as Vanuatu, and considering its presence in the isolated Micronesian Truk Group, it probably is readily dispersed.

\section{Checklist}

Acropsilus includes the following species:

albitibia sp. n. Australia (Queensland, Northern

Territory, Western Australia), Indonesia (Irian

Jaya), Papua New Guinea, Solomon Islands,

Vanuatu

boharti sp. n. Indonesia (Irian Jaya), Solomon

Islands

colmanisp. n. Papua New Guinea

eburneensis Couturier, 1978: 222. Ivory Coast

errabundus Lamb, 1922: 403. Seychelles

igori Negrobov, 1984: 1111. Tadzhikistan

kuranda sp. n. Australia (Queensland)

malaita sp. n. Solomon Islands

maprik sp. n. Papua New Guinea

minutus Hollis, 1964: 276. Indonesia (Sumatra). niger Loew, 1869: 298 (Chrysotus). Hungary,

western Europe, northern Africa, St. Helena I

nigricornis sp. n. Solomon Islands, Australia

(Queensland), Indonesia (Irian Jaya )

protractus Robinson, 1963: 830. Solomon Islands,

Australia (Queensland, Northern Territory,

Western Australia), Indonesia (Irian Jaya), Papua

New Guinea

putosa sp. n. Papua New Guinea

toma sp. n. Papua New Guinea

udot sp. n. Micronesia (Truk)

The protractus group of species (Acropsilus protractus, A. boharti, A. colmani, A. kuranda, A. malaita, and $A$. minutus) all have an incised, pubescent first flagellomere. I have seen additional species from the Philippines (врвм), Sabah and Peninsular Malaysia (AMs) and Taiwan (CMNH) which have antenna and hypopygia similar to $A$. protractus, and the group is rich in the Oriental-Australasian tropics. Possibly the West African A. eburneensis also belongs in this group. 
Acropsilus errabundus from the Seychelles is distinctive for being longer (body length 2.3-2.4, whereas most Acropsilus are 1.3-1.6), and the male has elongate legs and thorax, giving it a rather gracile and almost medeterine appearance. As well, the male $\mathrm{It}_{1}$ has a ventral row of short setae, not found in other Acropsilus, and it has eyes which join across the face so that the characteristic clypeal setae absent (they are present on the female, however). Finally, FIII of at least the male has an isolated anterior seta at $3 / 5$, which I regard as a MSSC, not a true anterior preapical seta. I have examined a male paratype from the Seychelles, Mahé (вмNн) and males from Silhouette, Corgate Ridge, $500 \mathrm{~m}$ (AMs).

I have not seen specimens of the Palaearctic Acropsilus igori. However, Negrobov's (1984) description does not note the presence of setae on the clypeus, nor the presence of a Y-shaped carina on sternum 8. As well, the hypopygial figure does not indicate the prominent cerci which are so distinctive on congeners. Possibly this species belongs elsewhere.

\section{Morphological notes}

Acropsilus is a well-defined genus, and most species conform to the general description given above. Morphological characters which relate to the taxonomic placement of Acropsilus are considered below.

\section{Autapomorphies}

1. Male sternum 8 has a distinctive inverted Yshaped carina (e.g. fig. 1). This carina is present on all the species I have examined, and is an autapomorphy for the genus. I know of no other dolichopodid genus with a similar structure.

2. The epandrial lobe in most Acropsilus species lies subparallel with and externally overlaps the surstyli (fig. 1).

3. The male tergum 1 is distinctly wider than succeeding segments, and wider than the thorax (fig. 17), on all species.

\section{Other Character States}

4. The subepandrial sclerite between the cerci is prominent, and often has a group of strongly pedunculate distal setae (e.g. fig. 1). Various other dolichopodid subfamilies (e.g. Dolichopodinae) also have well-developed subepandrial sclerites.

5. The clypeus of females and usually males has four projecting setae: pair midcentral shorter setae, and pair of stronger distal setae (as in fig. 15). Strikingly, the New World Atlantic coastal Nanomyina barbata (Aldrich) has similarly positioned setae (see fig. 5, Robinson \& Vockeroth 1981). Nanomyina also has an apical arista, but has 2 rows of ac and a rather short hypopygium (I have not seen specimens). This configuration of clypeal setae therefore is probably homo- plasious. As well, some other dolichopodid genera also have clypeal setae but in different configurations, for example, as a female secondary sexual character (FSSC), in species close to Syntormon flexible Becker, and in some undescribed Australian Sympycnus species.

6. Posterior mesonotum has a distinct transverse fold just anteriad of scutellum. This structure was noted by Ulrich (1980), and also occurs in Diaphorinae.

\section{Systematic position}

Acropsilus has been assigned variously to the Sympycninae, Peloropeodinae, or left incertae sedis. Of all established subfamilies, Acropsilus superficially appears to be close to the Medeterinae, with which it shares postabdominal similarities (an elongate segment 7 forming an external peduncle for the hypopygium), apical arista, hypandrium basally fused to epandrium, and reduced leg setation. However, Acropsilus lacks the two strong apomorphic features which define the Medeterinae: postcranium dorsally concave and posterior mesoscutum strongly flattened. Therefore it should be kept out of that subfamily.

In a recent paper, Grootaert \& Meuffels (1997) described the Oriental genus Griphomyia, and noted its similarity to Acropsilus. The two genera share a number of characters: body length mostly less than $2 \mathrm{~mm}$; dorsal postcranium flat; male eyes distinctly separated by face and clypeus; strong verticals and strong diverging ocellars present; thorax rather short and wide; posterior slope of mesonotum slightly flattened but not depressed; $5 \mathrm{dc}$ present; femora II and/ or III with rather weakly developed subapical anterior seta; legs weakly bristled; similar venation; hypopygium pedunculate; abdominal segment 7 prolonged, and separated into distinct tergum and sternum; hypandrium and aedeagus both short and emerging at an angle near base of epandrium; subepandrial sclerite (= 'dorsal appendage' in Grootaert \& Meuffels 1997) welldeveloped; female oviscapt divided into two hemitergites, each with crest of spine-like setae and with elongate digitiform process subtended by pedunculate setae.

In summary, there are strong similarities among Griphomyia and Acropsilus, in overall habitus (see fig. 1 in Grootaert \& Meuffels 1997), female oviscapt, and especially the male postabdominal structure (compare figures in this paper with those in Grootaert \& Meuffels 1997). The obvious differences between the two genera (aristal position, presence/absence of acrostichals, clypeal setae, and anal vein) are minor and not of subfamilial significance. The two genera might be regarded as sister taxa and certainly belong in the same subfamily. Grootaert \& Meuffels place both in the Peloropeodinae. However, I am not entirely sure of the definition of the Peloropeodinae, and Peloropeodes itself has a strikingly different male 
postabdomen to the two genera considered here. Only provisionally would I place Acropsilus and Griphomyia in the Peloropeodinae, pending further investigation of that subfamily.

\section{Key to male Acropsilus from Australia, Melanesia and Micronesia}

The following small-sized dolichopodid taxa are sympatric with Acropsilus in the Australasian region, and can be distinguished as follows:

A. Cryptophleps species also have an apical arista and lack ac setae, but all have a broken vein $\mathrm{M}$, lack the $\mathrm{m}$-cu cross vein, and have an encapsulated hypopygium.

B. Sympycninae of similar size have strong anterior preapical setae on FII and FIII, ac setae usually present, often a distal ad setal comb on TI, a dorsal arista and an encapsulated hypopygium.

C. Medeterinae also have a pedunculate hypopygium and apical arista, but have a distinctly concave dorsal postcranium, a strongly flattened posterior mesonotum, and lack the wide male tergum 1.

This key to Acropsilus is difficult and most species, apart from a few with obvious Mssc, require a genitalic preparation for accurate identification.

1. Cercus clavate, distally expanded with apex at least four times wider than base .........................2

- Cercus elongate, more or less digitiform, with apex not more than twice basal width ............... 3

2. Antenna mostly orange-yellow with only the tip of the first flagellomere dark brown; TIII with strong dorsal seta at $7 / 8$; cercus, expanded and clavate, subtriangular, and bearing distal row of strong long pale setae. and with dorsal setose projection. (fig. 12) (Papua New Guinea)

..A. mapriksp. n.

- Antenna dark brown; TIII with short dorsal setae on distal quarter; cercus, expanded and clavate, subtriangular, and bearing scattered pale setae (fig. 13) (Solomon Islands, New Guinea, Queensland) A. nigricornis sp. n..

3. Cercus expanded, elongate and spatulate; subepandrial sclerite broad with 3 strong apical setae (fig. 19) (Micronesia: Truk) ........... u. udotsp. n.

- Cercus not as above .............................................4.

4. First flagellomere only weakly incised, if at all, so that arista arises on the outer curvature of the first flagellomere (fig. 15)

- First flagellomere deeply incised, so that arista within distinct indentation on the outer curvature of the first flagellomere (fig. 4) ..................7

5. Entire antenna yellow, with pale hairs; TI and TII basally yellow, with distal three-quarters distinctly white, and tarsomeres $\mathrm{It}_{2-3}$ white; basal epandrial seta twice length of distal seta; cercus relatively short and curved (fig. 14); (tropical Australia, New Guinea, Solomon Islands, Vanuatu)

A. albitibia sp. $\mathrm{n}$.

- At least first flagellomere partially brown; tibiae and tarsi entirely yellow ....................................

6. Tibia III with long curved dorsal seta at $7 / 8$ (fig. 10); antenna dark brown; cercus with strong basal setae and apico-median field of short hairs (Papua New Guinea) A. toma sp. $\mathrm{n}$

- Tibia III with short dorsal setae; scape and pedicel yellow; first flagellomere mostly yellow with only apex infuscated; cercus digitiform and rather uniformly setose (fig. 6) (Papua New Guinea, montane) .................................... putosa sp. n.

7. Antenna with at least scape and pedicel partially yellow, and first flagellomere brown .................. 8

- Antenna entirely dark brown .............................

8. Cercus (fig. 11) lobate and elongate, almost twice as long as epandrium, and with distinctive dorsal digitiform projection which bears strong apical seta; mesonotum dull brown-yellow; (New Guinea, Solomon Islands) A. boharti sp. n.

- Cercus (fig. 1) short, about as long as epandrium, and subtriangular; thorax dark brown/metallic green (Solomon Islands, New Guinea, n. Australia ) ............................. protractus Robinson

9. Epandrial lobe greatly prolonged and lobate, completely covering surstylar arms, and subequal to elongate digitiform cercus (fig. 8) (Solomon Islands) .......................................... malaita sp. n.

- Epandrial lobe relatively short, not much longer than surstyli, and cerci subtriangular and tapering

. .10

10. Surstylus with dorsal arm strongly upcurved; cercus elongate, about as long as epandrium (fig. 7) (New Britain) ............................ colmani sp. n.

- Surstylus with arms subparallel; cercus lobate and short, not extending much beyond apex of surstyli. (fig. 5) (Queensland) .......A. kuranda sp. n.

\section{Acropsilus protractus Robinson}

(figs. 1-4, 20)

Acropsilus protractus Robinson 1963: 830. Holotype ô, SOLOMON ISLANDS: Guadalcanal, Lunga River Valley, 16.ix.1944, J. L. Laffoon (USNM) [examined].

Additional material (all records based on males). - AUsTRALIA. NORTHERN TERRITORY: Berry Springs, 12.42'S 130.59'E, monsoonal rainforest, 15.vi.1954 (ANIC), 4.xii.1991-9.i.1992, 27.ix-30.x.1991, 30.x-4.xii.1991, 9.i28.ii.1992, malaise, 9-11.i.1992, yellow pans (AMS); Birraduk Ck, $17 \mathrm{~km}$ WSW of Nimbuwah Rock, 12.19'S 133.13'E, 5.vi.1973; Cooper Ck, $11 \mathrm{~km} \mathrm{SW}$ of Nimbuwah Rock, 1.xi.1972; Kakadu NP, 19km NE of Baroalba Ck 


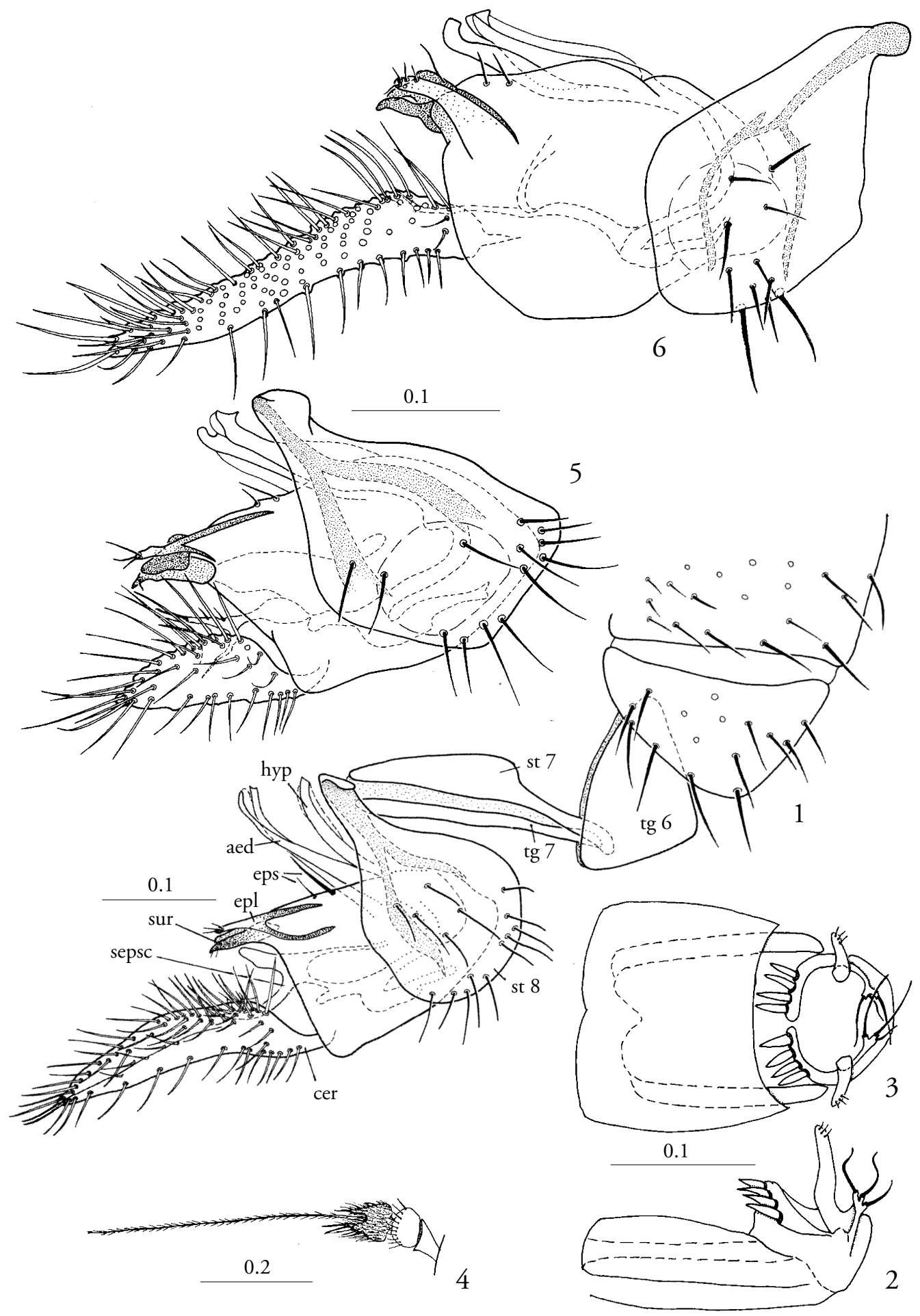


Springs, 12.48'S 132.49'E, 28.x.1972, malaise; East Alligator River, 5 km NNW of, 8-9-vi.1973 (ANIC); Koongarra, 16 km NE of Mt Cahill, 12.52'S 132.51'E, 10.iii.1973; Lee Point, 12.20'S 130.54'E, vi.1964; Magela Ck, $2 \mathrm{~km} \mathrm{~N}$ of Mudginbarry, 15.xi.1972; McArthur River, $2 \mathrm{~km} \mathrm{SSE} \mathrm{of}$ Borroloola, 20.iv.1976; Surprise Ck, 45 km SSW of Borroloola, 15.iv.1976 (ANIC). Kakadu NP, Gubara Springs carpark, 17.i.1992, pans (AMS). - QUEENSLAND: Cockatoo Creek, 11.39'S 142.27'E, 7.ii-2.iii.1993, 12.xi-14.xii.1993, malaise; Coen, 13.57'S 143.12'E, 16.viii-13.ix.1993, malaise; $1 \mathrm{~km}$ SE of Mt Cook, 15.30'S 145.16'E, 13.x.1980, malaise; 3.5km SSW of Mt Baird, 17.26'S 145.04'E, 4.v.1981, malaise; Bellenden Ker Range, $1 \mathrm{~km} \mathrm{~S}$ of Cable Tower 6, 17.x-5.xi.1981, malaise; Cedar Bay NP, Gap Ck, 5km ESE of Mt. Finnigan, 15.50'S 145.20'E, 150 m, 14.v.1981, malaise (ANIC), 14-15.iv.1994, pans (AMS); Davies Ck \& Goldmine Ck, Kuranda, 3.v.1967, gen/sweep; Earl Hill, N of Cairns, 16.48'S 145.42'E, 8.v.1967 (ANIC); Iron Range: $11 \mathrm{~km}$ ENE of Mt Tozer, 12.43'S 143.18'E, 11-16.vii.1986, malaise; 3km ENE of Mt Tozer, 12.45'S 143.14'E, 200 m, 28.vi-4.vii.1986, malaise; $9 \mathrm{~km}$ ENE of Mt Tozer, 12.43'S 143.17'E, 5-10.vii-1986, malaise; Mcllwraith Range, $11 \mathrm{~km}$ NW of Bald Hill, 13.39'S 143.20'E, 520 m, rainforest, 26.vi-13.vii.1989, malaise; Mossman Gorge, 16.26'S 145.16'E, 21-23.iv.1967; Mt Webb NP, 3 km NE of Mt Webb, 15.03'S 145.09'E, 1.v.1981, malaise; Rounded Hill, 15.17'S 145.13'E, 7.x.1980 (ANIC); Miriam Vale district, W of Eurimbula, 24.20'S 151.34'E, 29.iii.1975; Mt Windsor Tableland, Forestry Hut, 16.16'S 145.02'E, $1060 \mathrm{~m}$, 16.iv.1994, pans; Half Ton Ck, NE of Mt Carbine, 16.29'S 145.13'E, 290 m, riverine forest, 18.iv.1994, pans; Waterpark Ck SF, nr Byfield, 50 m, rainforest, 2.xii.1992; Cathu SF, O'Connell River, NW of Mackay, $30 \mathrm{~m}$, rainforest, 7.iv.1994, pans (AMS). - WESTERN AUSTRALIA: Carson Escarpment, Drysdale River, 14.49'S 126.49'E, 9-15.viii.1975, malaise (ANIC). - INDONESIA. IRIAN JAYA: Aru Islands, Trangan, $1 \mathrm{~km} \mathrm{~S}$ of Popjetur, 06.48'S 134.04'E, $90 \mathrm{~m}$, 23.vi11.vii.1994, malaise (NMWC). - PAPUA NEW GUINEA: Maprik, 21-22.iii.1964; Siutmeri, Sepik River, 16.iii.1964; Doa Estate, $80 \mathrm{~km} \mathrm{~W}$ of Port Moresby, 9.ix.1962; Eastern Highlands South, Okapa, 27.x.1964; Okapa, Kaga, 2,100 m, 11.vi.1964; Finisterre Range, Damaindi, Madang Central, 1060 m, x. 1964; Butemu III \& VIII, Finisterre Range, 1270 m, x.1964 (ANIC); Normanby I., Wamula 29.xii.19883.i.1989; Western Prov., Tabubil, 05.15'S 141.13’E, 650 m, 3.x.1993; Bainyik, 20.xii.1963 (AMs); Bougainville: Boku, 4.vi.1956, \& Ruisei, N of Tokinoitu, 2.vi.1956 (врвм). SOLOMON ISLANDS: Rennell Island, Niupani, 22.viii.1962 (zMUC); Guadalcanal, v.1944 (USNM); Vella Lavella, Arewana area, 17.xi.1963; Florida Group, Nggela I., Haleta, xi.1975, 0-50m; Kolombangara Island: Ringgi Cove, xi.1976 \& Kundulu, SW coast, 10.vii.1959; Guadalcanal, Honiara, 200 m, xii.1975; Guadalcanal, Tadhimbko, 9.xii.1975; Malaita, Auki, $100 \mathrm{~m}$, xii.1975; Malaita, NW, Dala, 11.vi.1964, light trap; New Georgia Group, Gizo I., 200 m, xii.1975, 11.vii.1959; New Georgia, Munda, 15.vii.1959; San Cristobal Island, Maniata, Kira Kira, xii.1975-i.1976; Santa Ysabel, Buala, 26.vi.1960, light trap (врвм).

\section{Description}

Male. - Length: 1.1 ; wing: $1.1 \times 0.3$.

Head. - Vertex and frons dark brown with metallic green reflections and some grey pruinosity; faceclypeus blue metallic green; palp and proboscis brownish; scape and pedicel reddish-yellow to yellow, although sometimes dorsally infuscated); first flagellomere dark brown, rounded, setose, and deeply incised.

Thorax. - Mesonotum dark brown with metallic blue-green reflections, with some grey pruinosity; pleura matt brown; proepisternum with pale longer ventral seta and 2 shorter dorsal setae near posterior margin.

Legs. - Coxae and remainder of legs yellow, although CII sometimes infuscated; CI and CII with short pale anterior hairs; CII and CIII each with short brownish lateral seta; I: $2.0 / 1.5 / 0.7 ; 0.5 ; 0.4 ; 0.2$; 0.2 ; leg I without distinctive setation; II: $2.0 / 2.2 / 0.8$; $0.5 ; 0.3 ; 0.3 ; 0.2$; TII with strong ad-pd pair at $1 / 4$, strong ad at $3 / 5$ and apically, and with strong ventral apical; III: $2.2 ; 2.1 ; 0.3 / 0.8 / 0.5 / 0.3 / 0.2$; TIII with short ad-pd pair at $1 / 4$, and dorsal seta at $7 / 8$; IIIt $_{1}$ somewhat globular and with a few ventral setae.

Wing. - Lower calypter yellow with fan of brown setae; halter yellow.

Abdomen. - Entirely dark brown with sparse short brown setae; hypopygium (fig. 1) brown, with dark brown surstyli, and cream-white cerci; hypopygial foramen left basolateral; hypandrium broad and apically upcurved; aedeagus rather short and slightly curved, and with notched phallus; ventral margin of epandrium with stronger basal and shorter well-separated epandrial setae; epandrial lobe with single apical seta and externally overlapping digitiform surstylar arms; cercus, expanded and clavate, subtriangular, and bearing long pale setae.

Female. - First flagellomere not as deeply incised; oviscapt (figs 3, 4) divided into two hemitergites, each with crest of 4 spine-like setae, and bearing elongate digitiform process and stalked group of pedunculate setae.

\section{Remarks}

Acropsilus protractus is widespread in northern Australia, New Guinea and the Solomon Islands (fig. 20), and is particular common in lowland habitats, but occurs to elevations of $2000 \mathrm{~m}$ in Papua New Guinea. In Australia, it is found across the monsoonal north, and along the Queensland coast south to the Tropic of Capricorn.

Figs. 1-6. Acropsilus species. - 1-4. Acropsilus protractus Robinson; 1, male postabdomen, left lateral; 2, female oviscapt, left lateral; 3, female oviscapt, dorsal; 4, male antenna, left lateral. - 5-6. hypopygium and sternum 8, left lateral - 5, A. kuranda sp. n.; 6, A. putosa sp. n. Abbreviations: aed, aedeagus; cer, cercus; epl, epandrial lobe; eps., epandrial seta; hyp, hypandrium; sur, surstylus; st, sternum; sepsc, subepandrial sclerite; tg, tergum. 
Acropsilus protractus has a yellow scape and pedicel in contrast to the dark brown first flagellomere, although in some specimens the dorsal scape and pedicel are infuscated. The legs are entirely yellow. The cerci appear somewhat apically truncated in dorsal view. As well, there is some intraspecific variation in cercal length, and specimens from northern Queensland appear to have slightly shorter cerci than Solomon Island specimens.

\section{Acropsilus kuranda sp. $\mathrm{n}$.}

(fig. 5)

Type material. - Holotype, $\hat{0}$, Paratypes, $\hat{\delta}, 2 q$, aUSTRALIA. QUeENSLAND: $11 \mathrm{~km}$ along Black Mountain, Kuranda State Forest, 20.iv.1967, D.H. Colless (ANIC).

Additional material. AUSTRALIA. QUEENSLAND: $\delta, 29$, Bellenden Ker Nat. Park, Bartle Frere track, at junction of 3 creeks, 17.25'S 145.51'E, $200 \mathrm{~m}$, rainforest, 12.iv.1994, pans; $\delta$, Eungella NP, Crediton Creek, 920 m, rainforest, 30.xi.1992, pans; ô, 2 ㅇ, Little Cooper Creek, 16.10'S 145.27'E, 75 m, rainforest, 14.iv.1994; ô, Mason Ck, nr Cape Tribulation, 16.05 'S 145.28 'E, 0-10 m, mangroves, 14-15.iv.1994, pans; $\widehat{0}$, Mount Mirinjo, 18 km NW of Innisfail, 25.iv.1980, sweep (AMs); 20 , $\uparrow$, Mt Elliot NP, Alligator Creek, 19.30'S 146.55'E, 30, sweep, 8.iv.1994 (CNC); o, 2 ㅇ, Bramston Beach, nr Innisfail, rainforest, 30.iv.1967; ๙ै, Gillies Hwy, $3.5 \mathrm{~km}$ W of Little Mulgrave, 18.iv.1967; 20, ㅇ, Laceys Creek, near Mission Beach, 17.54'S 146.06'E, 13-14.v.1980; 30ิ, 11 ๆ, Mcllwraith Range, $11 \mathrm{~km}$ NW of Bald Hill, 13.39'S 143.20'E, $520 \mathrm{~m}$, rainforest, 26.vi-13.vii.1989, malaise, 30 , The Boulders, NW of Babinda, 17.22'S 145.55'E, 50 m, 10.v.1967, 8.vii.1967; ๙ิ, + , Upper Mulgrave River, $16 \mathrm{~km}$ from Goldsborough, 9.v.1967; ơ, Wongabel SF, near Atherton, 17.19'S 145.31'E, 5.v.1967 (ANIC)

\section{Description}

Male. - Length: 1.3; wing: $1.1 \times 0.3$.

Head. - Vertex, frons dark brown with metallic blue reflections; face-clypeus metallic green; palp and proboscis brown; antenna dark brown, first flagellomere rounded, strongly setose, and deeply incised (as in fig. 4), with apical arista arising from base of incision.

Thorax. - Mesonotum dark brown with metallic blue-green reflections, and with little pruinosity; pleura matt brown; proepisternum with longer ventral seta and 2 shorter dorsal setae near posterior margin.

Legs. - Coxae and remainder of legs yellow; I: $1.8 /$ $1.7 / 0.7 ; 0.5 ; 0.4 ; 0.3 ; 0.3$; II: $2.3 / 2.5 / 0.8 ; 0.7 ; 0.3$; $0.3 ; 0.2$; TII with strong ad-pd pair at $1 / 4$, strong ad at $3 / 5$, and with strong ventral apical; III: $2.6 ; 2.7 ; 0.3 /$ $0.8 / 0.5 / 0.3 / 0.2$; TIII with short ad-pd pair at $1 / 4$, and a few short dorsal setae on distal quarter; IIIt somewhat globular and with a few ventral setae.

Wing. - Lower calypter yellow with fan of brown setae; halter yellow with dark brown club.

Abdomen. - Entirely dark brown with sparse short brown setae; sternum 8 with setae as figured; hypopygium (fig. 5) brown with dark brown surstyli and cream-white cerci; hypopygial foramen left basolateral; hypandrium broad and apically upcurved; aedeagus rather short and slightly curved, and with notched phallus; ventral margin of epandrium with stronger basal and shorter distal epandrial setae; epandrial lobe with 2-3 apical setae, and externally overlapping subtriangular surstylar arms; subepandrial sclerite Y-shaped with two apical arms, each ending in strong seta; cercus lobate, bearing long pale setae, and not extending much beyond apex of surstyli.

Female. - Similar to male except as noted: eyes slightly more widely separated, and facets of uniform size; first flagellomere not as deeply incised; IIIt $_{1}$ somewhat less swollen.

\section{Remarks}

Acropsilus kuranda occurs in tropical forests of northeastern Queensland, from the McIlwraith Range of Cape York Peninsula south to Eungella, west of MacKay. Most specimens were taken in the Cairns district. This species is close to the sympatric $A$. protractus, but differs in having the antenna entirely dark brown, a short lobate cercus which doesn't extend much beyond the surstyli, and a more deeply incised first flagellomere.

\section{Acropsilus colmani sp. $\mathrm{n}$.}

(fig. 7)

Type material. - Holotype, $\widehat{0}$, Paratypes $5 \hat{0} 2 q$, papua new guinea, New Britain, Amelei Village, Fullerborn Harbour, xii.1988, P H Colman (AMs).

Additional material. - PAPUA NEW GUINEA, $\delta$, $q$, New Britain, Keravat, Rabaul, 100 m, 15-31.x.1968, N L H Krauss (врвм); $\widehat{o}$, Kandanggei, Sepik River , 2.iii.1964 (ANIC).

\section{Description}

Male. - Length: 1.2-1.3; wing: $1.1 \times 0.4$.

Head. - Vertex, frons dark brown with metallic green reflections clypeus and face bright metallic green; palp and proboscis brown; antenna uniformly dark brown, first flagellomere rounded, setose, but only shallowly incised.

Thorax. - Mesonotum dark brown with metallic blue-green reflections, and shining, with little pruinosity; pleura matt brown; proepisternum with longer ventral seta and 2 shorter dorsal setae near posterior margin.

Legs. - Coxae and remainder of legs yellow; TII with strong ad-pd pair at $1 / 4$, strong ad at $3 / 5$, and with strong ventral apical; TIII with short ad-pd pair at 1/4, 

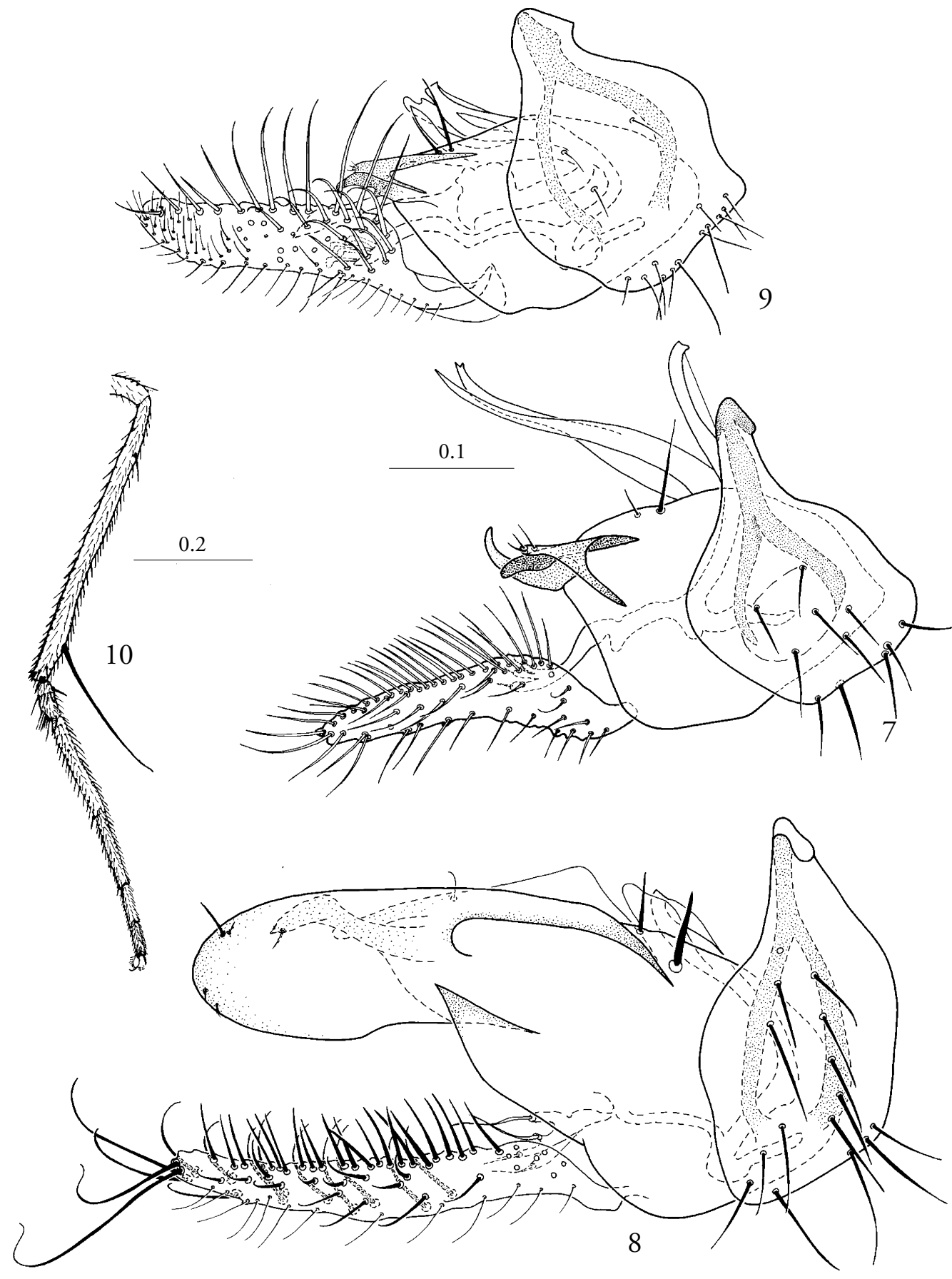

Figs. 7-10. Acropsilus species. -7-9, hypopygium and sternum 8, left lateral; 10, male tibia and tarsus III, anterior; - 7, Acropsilus colmani sp. n.; 8, A. malaita sp. n.; 9-10, A. toma sp. n. 
and a few short dorsal setae on distal quarter; IIIt ${ }_{1}$ somewhat globular and with a few ventral setae.

Wing. - Lower calypter yellow with fan of brown setae; halter yellow with brownish club.

Abdomen. - Preabdomen dark brown with sparse short brown setae, postabdomen mostly light brown except hypopygium with dark brown surstyli and elongate cream-white cerci; hypopygium (fig. 7); hypandrium broad and upcurved apically; aedeagus curved, and with notched phallus; ventral margin of epandrium with well-separated strong basal and shorter epandrial setae; epandrial lobe with short apical setae, and externally overlapping surstylus; surstylus dark brown, with dorsal arm strongly upcurved; subepandrial sclerite cercus with 4 strong apical setae, each on distinct peduncle; elongate and oblong, and bearing pale setae.

Female. - Similar except lack MSsC and as noted: abdomen entirely dark brown.

\section{Remarks}

Acropsilus colmani is known from New Britain and mainland Papua New Guinea. This species is close to A. protractus and also has a hairy, incised first flagellomere. However, the combination of entirely dark brown antenna, elongate cercus, and upcurved surstylar arm are diagnostic. This species is named for Phil Colman, who has collected extensively in Melanesia.

\section{Acropsilus malaita sp. n.} (fig. 8)

Type material. - Holotype, $\widehat{0}$, Solomon Islands: Malaita (NW), Dala, 5.vi.1964, light trap, R. Straatman (вРвм).

\section{Description}

Male. - Length: 1.3 ; wing: $1.2 \times 0.3$.

Head. - Vertex and frons dark brown with metallic reflections; face clypeus metallic green; antenna dark brown, first flagellomere rounded, weakly setose, and only slightly incised.

Legs. - Coxae and remainder of legs yellow; TII with strong ad-pd pair at $1 / 4$, strong ad at $3 / 5$, and with strong ventral apical; TIII with short ad-pd pair at $1 / 4$, and short dorsal setae near $7 / 8 ; \mathrm{It}_{1}$ somewhat globular and with ventral setae.

Wing. - Lower calypter yellow with fan of brown setae; halter yellow with infuscated club.

Abdomen. - Entirely dark brown with sparse short brown setae; hypopygium (fig. 8) with dark brown surstyli, and cream-white cerci; hypandrium broad and apically upcurved; aedeagus rather short and slightly curved; ventral margin of epandrium with very strong basal epandrial seta which is somewhat laterally displaced and shorter distal epandrial seta; epandrial lobe dark brown, greatly expanded and distally prolonged with some short apical setae, and totally covering the more median surstylar arms, one of which is distally bent; subepandrial sclerite cercus with 4 strong apical setae, each on distinct peduncle; cercus elongate and digitiform.

Female. - Unknown.

\section{Remarks}

Acropsilus malaita is known only from the Malaita, Solomon Islands type locality. The greatly prolonged and expanded epandrial lobe and elongate digitiform cercus are diagnostic.

\section{Acropsilus toma sp. n.}

(figs. 9-10)

Type material. - Holotype, $\widehat{\delta}$, Paratypes $q$, PAPUA NEW GUINEA: Mangalese area, nr Toma, SSW of Popendetta, 600 m, ix.1964, R. Pullen (ANIC).

Additional material. - PAPUA NEW GUINEA: $\hat{\sigma}$, Central Prov., Port Moresby, 29.v.1984 (CMNH).

\section{Description}

Male. - Length: 1.3; wing: $1.1 \times 0.3$.

Head. - Vertex, frons, face, clypeus dull dark brown; palp and proboscis brown; antenna dark brown, first flagellomere rounded, not densely haired and only weakly incised, with apical arista arising from base of incision.

Thorax. - Mesonotum dark brown with some brown pruinosity; pleura matt brown; setae black.

Legs. - Coxae brown but yellowish distally; remainder of legs yellow, although femora somewhat infuscated; TII with strong ad-pd pair at $1 / 4$, strong ad at $3 / 5$, and with strong ventral apical; TIII (fig.10) with short ad seta at $1 / 5$ and with very long curved dorsal seta at 7/8 (MSSC); IIIt ${ }_{1}$ somewhat globular and with some ventral setae.

Wing. - Lower calypter yellow with fan of brown setae; halter brownish with dark brown club.

Abdomen. - Entirely dark brown with sparse short brown setae; hypopygium (fig. 9) brown with dark brown surstyli and white cerci; hypandrium broad and apically upcurved; aedeagus curved, and with notched phallus; ventral margin of epandrium with stronger basal and slightly shorter distal epandrial setae; epandrial lobe externally overlapping surstylar arms; subepandrial sclerite curved and elongate, with apical setae; cercus oblong, bearing row of long pale ventral setae and field of strong curved basomedial seat, and with apicomedial field of short hairs.

Female. - Similar to male except as noted: eyes slightly more widely separated, and facets of uniform size; TIII with only short dorsal seta at $7 / 8$. 


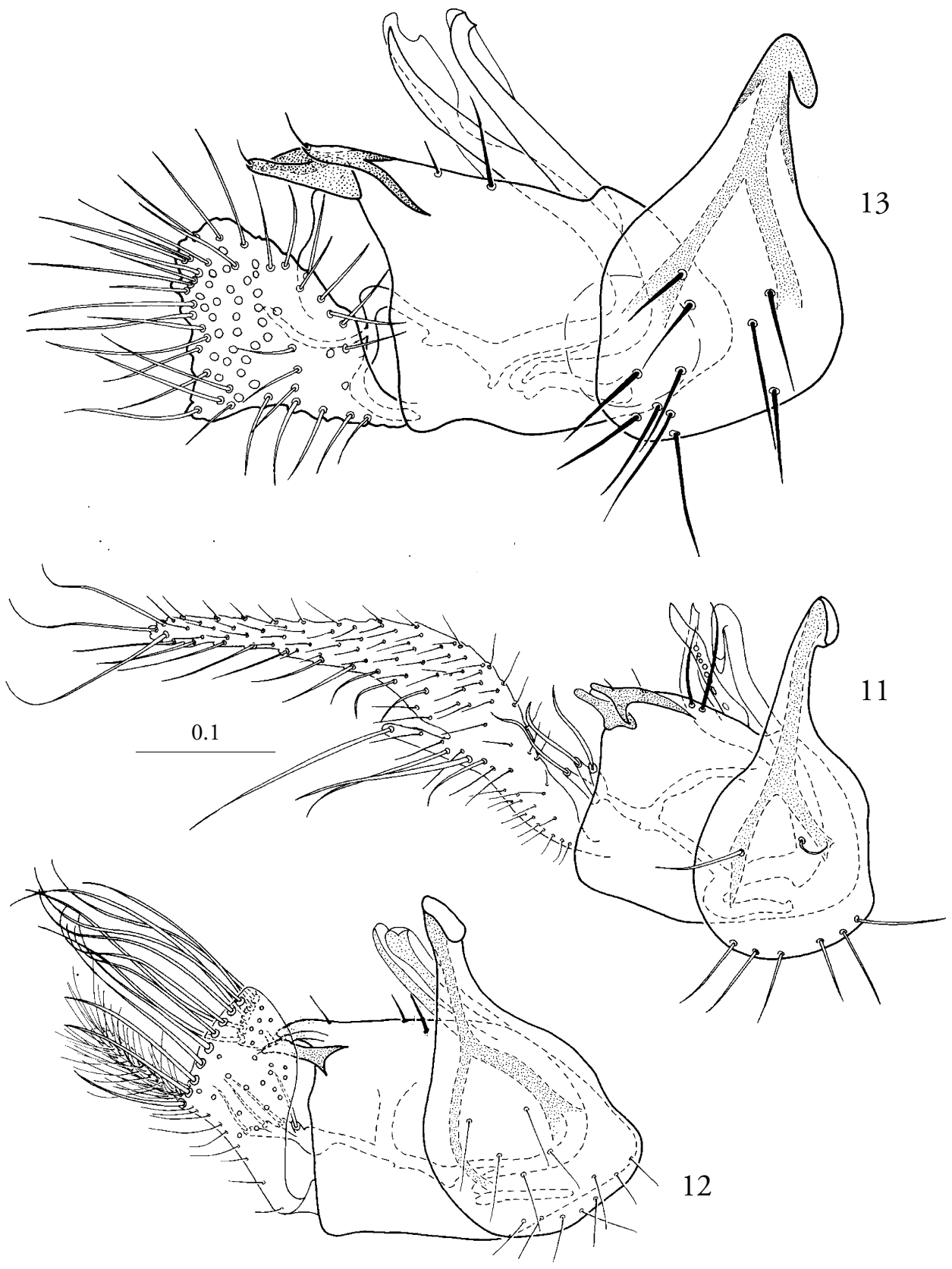

Figs. 11-13, Acropsilus species, hypopygium and sternum 8, left lateral. - 11, Acropsilus boharti sp. n.; 12, A. maprik sp. n.; 13, A. nigricornis sp. $\mathrm{n}$. 


\section{Remarks}

Acropsilus toma is known from two lowland sites in Papua New Guinea. It is distinguished by the long curved dorsal seta of male tibia III (MSSC), and the row of long setae along the ventral border of the oblong cerci.

\section{Acropsilus boharti sp. n.}

(fig. 11)

Type material. - Holotype, $\hat{0}$, Paratypes, $\hat{0}, 2 q$, INDONESIA. IRIAN JAYA, Biak I., 25.iv.1945, G.E. Bohart (CAS).

Additional material. - SOLOMON IsLANDS: $\hat{0}$, Guadalcanal, Tambalia, $30 \mathrm{~km} \mathrm{~W}$ of Honiara, malaise trap, 21.v.1964 (врвм).

\section{Description}

Male. - Length: 1.2 ; wing: $1.3 \times 0.4$.

Head. - Vertex, frons dark brown with metallic reflections; face-clypeus metallic blue-green; palp and proboscis yellowish; antenna yellowish with first flagellomere slightly infuscated; first flagellomere rounded, strongly setose and incised, with apical arista arising from base of incision.

Thorax. - Mesonotum dull brown-yellow with litthe pruinosity; pleura yellow.

Legs. - Coxae and remainder of legs yellow; TII with ad-pd pair at $1 / 4$, strong ad at $3 / 5$, and with strong ventral apical; TIII with short ad-pd pair at $1 / 4$, and strong subapical dorsal seta; IIIt $_{1}$ somewhat globular and some ventral setae.

Wing. - Lower calypter yellow with fan of brown setae; halter yellow with dark brown club.

Abdomen. - Entirely dark brown with sparse short brown setae; hypopygium (fig. 11) brown with dark brown surstyli and white cerci; hypandrium broad and apically upcurved; aedeagus curved with indented phallus; ventral margin of epandrium with strong basal and distal epandrial setae; epandrial lobe with short setae and externally overlapping rather short surstylar arms; subepandrial sclerite with group of 3 strong setae, each arising from separate long peduncle; cercus elongate and lobate, bearing pale setae, and with distinctive dorsal digitiform projection which bears strong apical seta.

Female. - Similar to male except as noted: eyes slightly more widely separated, and facets of uniform size; first flagellomere not as deeply incised; IIIt $_{1}$ somewhat less swollen.

\section{Remarks}

Acropsilus boharti is known from two lowland Me- lanesian sites: Biak Island off northern Irian Jaya, and Guadalcanal, Solomon Islands, but it probably occurs in intervening areas. This species is distinguished by the digitiform projection along the dorsal surface of the elongate cercus. This digitiform projection is longer on the Irian Jaya males (figured) than on the Solomon Island male.

Acropsilus maprik sp. n.

(fig. 12)

Type material. - Holotype, $\widehat{0}$, PAPUA NEW GUINEA: Maprik, 21.iii.1964, D.H. Colless (ANIC).

\section{Description}

Male. - Length: 0.9; wing: $1.2 \times 0.4$

Head. - Vertex and frons dark brown, with metallic green reflections; face-clypeus metallic green-bronze; palp and proboscis brown; antenna mostly orangeyellow with only the tip of the first flagellomere dark brown; first flagellomere rounded, setose, and only shallowly incised.

Thorax. - Dark brown with metallic blue-green reflections, and shining, with little pruinosity; pleura matt brown.

Legs. - Coxae and remainder of legs yellow, although FII and FIII slightly infuscated; TII with strong ad-pd pair at $1 / 4$, strong ad at $3 / 5$, and with strong ventral apical seta; TIII with short ad-pd pair at $1 / 4$, and strong dorsal seta at $7 / 8$; IIIt $_{1}$ with ventral roe of short hairs (MSSC).

Wing. - Lower calypter yellow with fan of brown setae; halter yellow.

Abdomen. - Preabdomen dark brown with sparse short brown setae; postabdomen and hypopygium (fig. 12) mostly yellow, except hypopygium with dark brown surstyli and ivory-white cerci; hypandrium broad and apically upcurved; aedeagus rather short and slightly curved; ventral margin of epandrium with stronger basal and shorter epandrial setae; epandrial lobe with single apical seta and externally overlapping digitiform surstylar arms; subepandrial sclerite with 4 strong, slightly pedunculate setae; cercus, expanded and clavate, subtriangular, and bearing distal row of strong long pale setae, and with medio-dorsal setose projection.

Female. - Unknown.

\section{Remarks}

Acropsilus maprik is known only from northern lowland Papua New Guinea. The enlarged clavate cercus with its distal row of strong setae and yellow antennae are diagnostic. This species is close to $A$. nigricornis and both species have clavate cerci. 
Acropsilus nigricornis sp. $\mathrm{n}$.

(fig. 13)

Type material. - Holotype, $\widehat{0}$, solomon ISLANDS. New Georgia Group, Gizo I., 0-100 m, ii.1984, N. L. H. Krauss (врвм).

Additional material. - AUSTRALIA. QUEENSLAND: $\hat{\delta}$, Iron Range, nr. Mt Lamond, 20.xii.1971 (AMs); $\hat{\sigma}$, Mt Webb NP, 3 km NE of Mt Webb, 15.03'S 145.09'E, 2.x.1980, malaise trap (ANIC). - INDONESIA. IRIAN JAYA: $\hat{\sigma}$, Biak I., 25.iv. 1945 (CAS).

\section{Description}

Male. - Length: 1.1 ; wing: $1.0 \times 0.3$.

Head. - Vertex, frons, face-clypeus metallic green, dark brown, shining with metallic blue reflections; palp and proboscis brown; antenna dark brown, first flagellomere rounded, setose, and weakly incised.

Thorax. - Mesonotum dark brown with metallic blue-green reflections, and with little pruinosity; pleura matt brown; proepisternum with longer ventral seta and 2 shorter dorsal setae near posterior margin.

Legs. - Coxae and remainder of legs yellow; I: $2.0 /$ $1.5 / 0.7 ; 0.3 ; 0.3 ; 0.2 ; 0.2$;II $2.0 / 2.2 / 0.8 ; 0.5 ; 0.3$; $0.3 ; 0.2$; TII with strong ad-pd pair at $1 / 4$, strong ad at $3 / 5$, and with strong ventral apical; III: $2.2 ; 2.1 ; 0.3 /$ $0.8 / 0.5 / 0.3 / 0.2$; TIII with short ad-pd pair at $1 / 4$, and a few short dorsal setae on distal quarter; IIIt somewhat globular and with a few ventral setae.

Wing. - Lower calypter yellow with fan of brown setae; halter yellow.

Abdomen. - Entirely dark brown with sparse short brown setae; hypopygium (fig. 13) brown, with dark brown surstyli, and cream-white cerci; hypandrium broad and apically upcurved; aedeagus rather short and slightly curved; ventral margin of epandrium with well- separated stronger basal and shorter epandrial setae; epandrial lobe with single apical seta and externally overlapping digitiform surstylar arms; subepandrial sclerite with distal curved Y-shaped arms; cercus, expanded and clavate, subtriangular, and bearing scattered long pale setae.

Female. - Unassociated.

\section{Remarks}

Acropsilus nigricornis is known from the Solomon Islands, Cape York Peninsula, and offshore northern Irian Jaya. The enlarged clavate cercus, dark brown, weakly-incised first flagellomere, and shining metallic blue face are diagnostic.

\section{Acropsilus albitibia sp. n.}

(figs. 14-18, 21)

Type material. - Holotype $\hat{\delta}$, Parartypes $4 \hat{0}, 3$, AUSTRALIA. QUEENSLAND: Iron Range, $3.2 \mathrm{~km} \mathrm{NE}$ of
Mt Lamond, 22.xii.1971, D.K. McAlpine \& G.A. Holloway. Paratypes, $8 \delta^{\star}, 21 \uparrow, 1.6 \mathrm{~km}$ W of Mt Lamond, 13-23.xii.1971, malaise; 40ิ, 2 으, Claudie River, nr Mt Lamond, 12.48'S 143.13'E, 3.vi.1966 (AMs).

Additional material (all records based on males). - AUsTRALIA. NORTHERN TERRITORY: Berry Springs, 12.42'S 130.59'E, monsoonal rainforest, 30.x-4.xii.1991, 4.xii.19919.i.1992, malaise (AMS); Darwin, 12.27'S 130.50'E, vivii.1958, at light (ANIC); Kakadu NP, Baroalba Ck Springs, $19 \mathrm{~km}$ NE of Mt. Cahill, 12.48'S 132.49'E, 29.x.1972, malaise \& 16.xi.1972, at light (ANIC); Nourlangie Ck, 8 km $\mathrm{N}$ of Mt Cahill, 26.x.1972; Lee Point, 12.20'S 130.54'E, vi.1964 (ANIC); Magela Ck, $2 \mathrm{~km} \mathrm{~N}$ of Mudginbarry, 15.xi.1972 (врвм). - QUEENSLAND: $14 \mathrm{~km} \mathrm{NW}$ of Hope Vale Mission, 15.16'S 144.49'E, 8.x.1980, malaise; 1 km SE of Mt Cook, 15.30'S 145.16'E, 13.x.1980, malaise; 4 $\mathrm{km}$ SSE of Cape Tribulation, 16.06'S 145.29'E, 2122.xi.1981; 5 km NW of Rounded Hill, 15.17'S 145.10'E, 7.x.1980, malaise; Bamboo Ck, nr Mail, 16.19'S 145.23’E, 25.iv.1967; Cedar Bay NP, Gap Ck, 5 km ESE of Mt Finnegan, 15.50'S 145.20'E, 150 m, 15.v.1981, malaise; Earl Hill, N of Cairns, 16.48'S 145.42'E, 8.v.1967; Gillies Highway, $3 \mathrm{~km} \mathrm{~W}$ of Little Mulgrave, 18.iv.1967; Iron Range, 3 km ENE of Mt Tozer, 12.45'S 143.14'E, 200 m, 28.vi-4.vii.1986, malaise; 9 km ENE of Mt Tozer, 12.43'S 143.17'E, 5-10.vii.1986, malaise; $9 \mathrm{~km} \mathrm{NW}$ of Mt Tozer, 30-vi-7.vii.1986; Laceys Ck, nr Mission Beach, 17.54’S 146.06'E, 13-14.v.1980; Station Ck, 7 km WSW of Hope Vale Mission, 15.19'S 145.03'E, 10.v.1981; The Boulders, NW of Babinda, 17.22'S 145.55'E, 50 m, 8.vii.1971; McIlwraith Range, $11 \mathrm{~km}$ NW of Bald Hill, 13.39 'S 143.20 'E, 520m, rainforest, 26.vi-13.vii.1989, malaise; Mt Cook NP, 15.29'S 145.16'E, 10.v.1981, 12.x.1980, malaise; Mt Webb NP, 3 km NE of Mt Webb, 15.03'S 145.09'E, 1-2.v.1981, malaise (ANIC); North Maria Ck, nr Silkwood, 17.45'S 146.02'E, 14.xii.1961; Double Mouth Ck, $30 \mathrm{~km} \mathrm{NE}$ of Heathlands, 11.37'S 142.49'E, 22.iii.1992; Portland Roads, 12.36'S 143.25'E, 14.xii.1971, malaise; Silkwood, 17.45'S 146.01'E, 25.v.1958; Tully River, 17.46'S 145.36'E, 175 $\mathrm{m}$, rainforest, 10.iv.1994, pans; Bertie Ck pump, nr Heathlands, 11.46'S 142.36'E, 21.iii.1992, malaise (AMS). - WESTERN AUSTRALIA: Kimbolton, xi-xii.1982, malaise (ANIC). IndOnESIA: Aru Islands, Trangan, $1 \mathrm{~km} \mathrm{~S}$ of Popjetur, 06.48'S 134.04'E, 90 m, 23.vi-11.vii.1994, malaise trap (NMWC); - IRIAN JAYA: Biak I., 25.iv.1945 (CAS); Oransbari, 28.vii.1962 (врвм). - PAPUA NEW Guinea. Central Prov.: Doa Estate, 80 km W of Port Moresby, 2-9.ix.1962 (ANIC); $5 \mathrm{~km} \mathrm{NW}$ of Brown River Bridge, 6.ix.1984; Aroa River, Aroana Estate, 2.xii.1963, 26.viii.1984; Imbia, nr Maprik, 19.xii.1963 (AMs); Rouna, 300 m, xi.1968; Brown River, dry riverbed, 30.viii.1959 (вРBM). - SOLOMON ISLANDS. Guadalcanal, Honiara, 200 m, xii.1975; Guadalcanal, Poha River, 5 m, 2.vii.1959; Malaita, Auki, 100 m, 18.xi.1957; New Georgia Group, Ghizo I., 200 m, xii.1976, malaise; Rendova Island, Agagana, 13.xi.1970; Dai Island, Bethlehem, 10 m, xii.1972 (врвм). - vanuatu. Lopevi, Lamen, $100 \mathrm{~m}$, ii.1976 (врвм).

\section{Description}

Male. - Length: 1.2 ; wing $1.1 \times 0.4$

Head. - Vertex and frons dark brown with metallic green reflections; face and clypeus bright metallic green; palp and proboscis brown; antenna entirely red- 

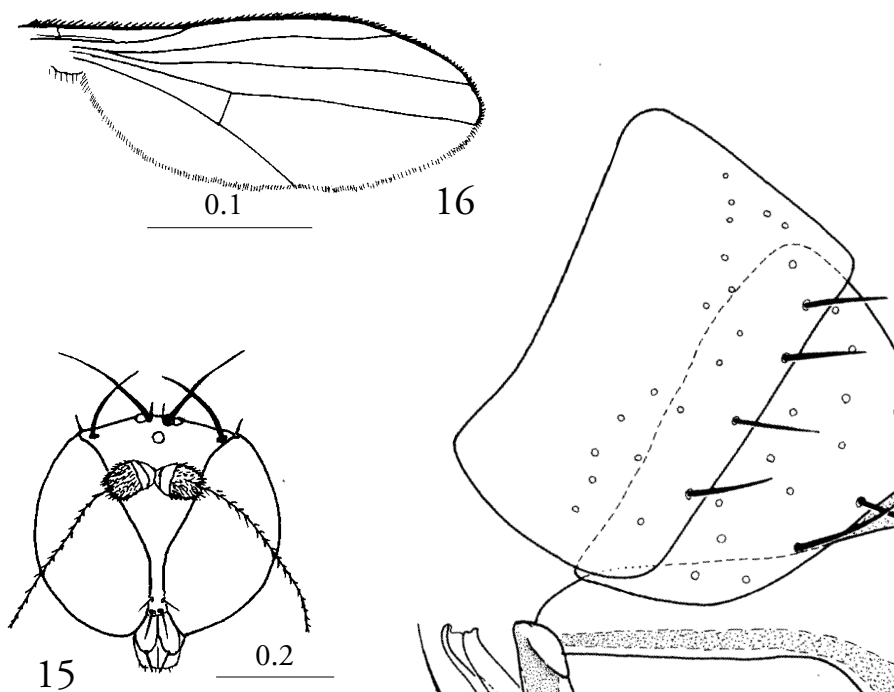

15
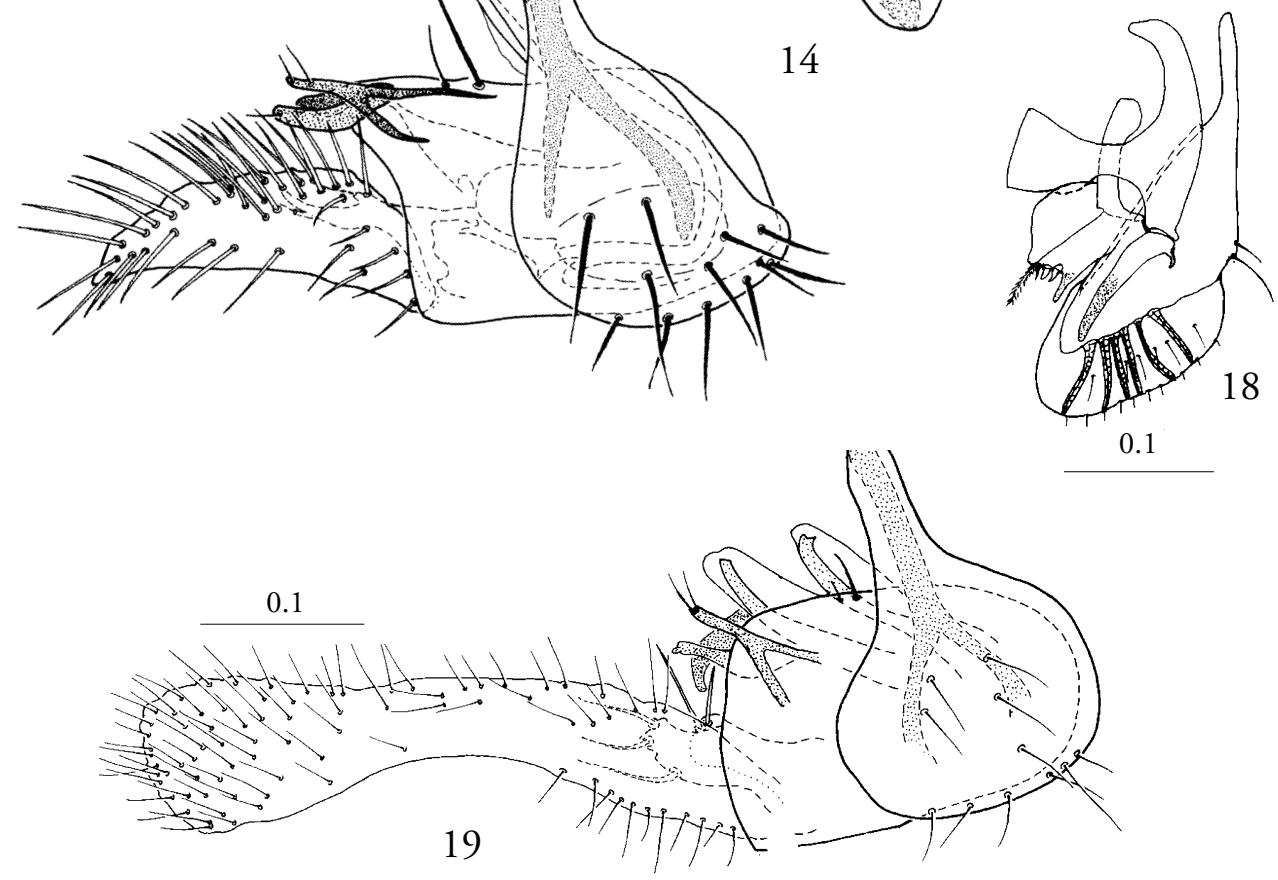

Figs. 14-19. Acropsilus species. - 14-18. Acropsilus albitibia sp. n.; 14, male postabdomen, left lateral; 15, male head, anterior; 16, male wing, dorsal; 17, male thorax and abdomen, posterodorsal; 18, internal mouthparts, left lateral; 19, A. udotsp. n., hypopygium and sternum 8 , left lateral. 


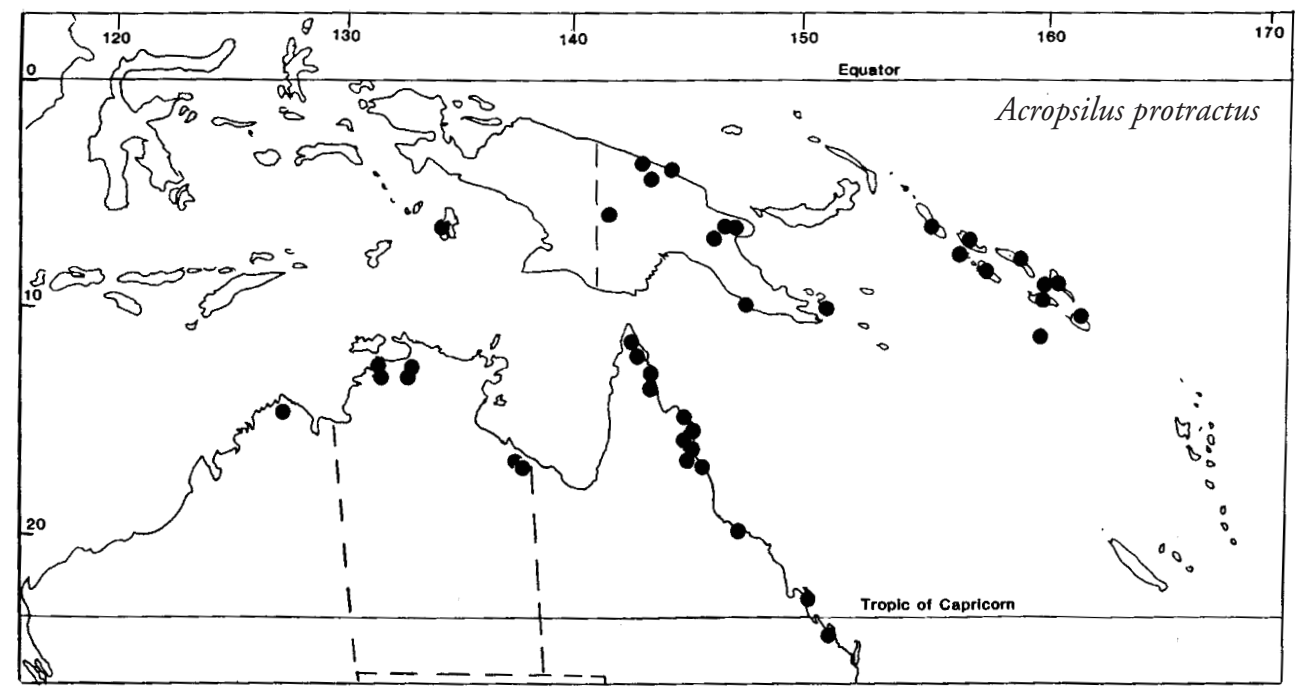

Fig. 20. - Distribution, Acropsilus protractus Robinson.

dish-yellow; first flagellomere rounded, globular, with pale apical hairs, but without apical notch (fig. 15).

Thorax. - Brownish with metallic green reflections, with some brown pruinosity over mesonotum and pleura, and with humeral area yellowish; proepisternum with 3 short spaced setae near posterior margin; setae black.

Legs. - Coxae and femora yellow; TI and TII basally yellow, with distal three-quarters distinctly white or ivory coloured (MSSC), and especially visible in anterior view, strongly contrasting with yellow ground colour; TIII pale yellow; tarsi mostly yellow, but $\mathrm{It}_{2-3}$ white (MSSC); CI and CII with short pale anterior hairs; CIII and CIII each with short brown lateral seta; I: $2.7 / 2.2 / 0.8 ; 0.4 ; 0.3 ; 0.4 ; 0.4$; leg I without distinctive setation; II: $3.6 / 3.2 / 1.0 ; 0.8$; $0.4 ; 0.4$; 0.4 ; FII with short subapical av and pv setae; TII with strong ad-pd pair at $1 / 4$, strong anterior at and apically, and with strong apico-ventral seta; III: 3.0 ; 3.4; $0.4 / 1.2 / 0.6 / 0.5 / 0.4$; FIII with short subapical av and pv setae; TIII with strong ad and pd at $1 / 4$, and with strong subapical dorsal seta; IIIt $_{1}$ somewhat globular with short ventral setae.

Wing (fig. 16). - Lower calypter yellow with fan of brown; halter yellow.

Abdomen. - Preabdomen (fig. 17) dark brown with short yellowish setae; postabdomen (segments 6-9) and hypopygium yellowish, except surstyli dark brown and cerci ivory white; hypopygium (fig. 14); hypandrium broad and hood-like; ventral margin of epandrium bearing very strong basal epandrial seta and shorter distal seta; epandrial lobe digitiform with apical and subapical setae; surstylar arms slightly curved and digitiform; subepandrial sclerite elongate, with basal and distal pedunculate setae; cercus subtriangular and tapering and covered with white setae.

Female. - Similar to male except lack MSsC and as noted: face wider; TI and TII entirely yellow; abdomen dark brown.

\section{Remarks}

Acropsilus albitibia is found in monsoonal northern Australia, from Cape York Peninsula to the Kimberley district, Western Australia, and widely across lowland Melanesia, from the Aru Islands and mainland New Guinea to the Solomon Islands and Vanuatu (fig. 21).

The ivory-white colour on male tibiae I and II is diagnostic. In addition, most males have similar white tarsomeres 2-3 on leg I, but this is sometimes indistinct, so that tarsus I appears entirely pale yellow. Also it should be noted that in some specimens the white coloration on tibiae I and II is only weakly developed. This might be due to age, state of preservation, or intraspecific variation. Of particular interest, the ivorywhite colour on both male legs I and II is identical to the male cercal colour (and the cercal colour of most Acropsilus species), and possibly both the legs and cerci are used in courtship display. 


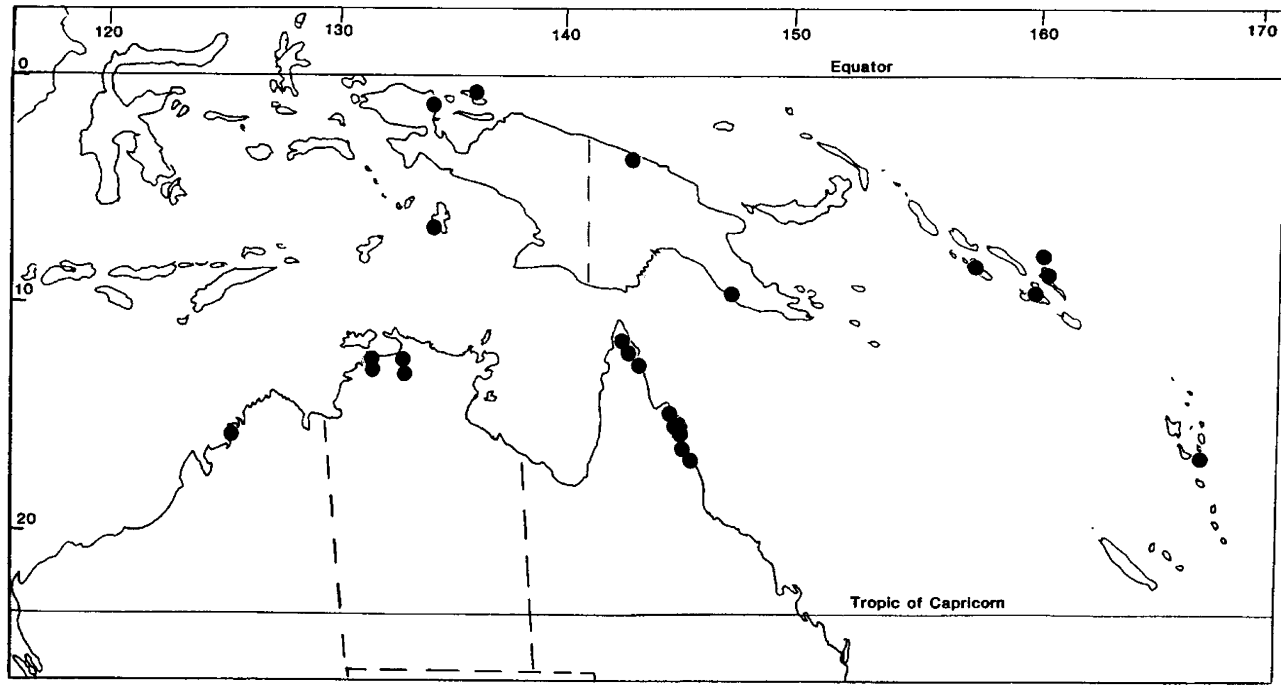

Fig. 21. - Distribution, Acropsilus albitibia sp. n.

Acropsilus putosa sp. n.

(fig. 6)

Type material. - Holotype $\widehat{\delta}$, Paratype $\hat{\sigma}$ PAPUA NEw Guinea. Eastern Highlands, Putosa, 2400 m (as 8000 ft.), vii.1968, R. Hornabrook (ANIC).

\section{Description.}

Male. - Length: 1.3 ; wing: $1.6 \times 0.5$.

Head. - Vertex and frons dark brown with metallic green reflections and some grey pruinosity; faceclypeus blue metallic green; palp and proboscis brownish; scape and pedicel yellow; first flagellomere mostly yellow with only apex infuscated, and rounded, not incised, and weakly haired.

Thorax. - Mesonotum dark brown with metallic blue-green reflections, with some grey pruinosity; pleura matt brown; proepisternum in basal third with longer ventral seta and shorter dorsal seta near posterior margin.

Legs. - Coxae yellow, although CII with some basal infuscation; femora mostly brown, and remainder of legs yellow, TII with strong ad-pd pair at $1 / 4$, strong ad at $3 / 5$, and with strong ventral apical; TIII with short ad-pd pair at 1/4, and short dorsal setae at 7/8; IIIt somewhat globular and with a few ventral setae.

Wing. - Lower calypter yellow with fan of brown setae; halter yellow.

Abdomen. - Entirely dark brown with sparse short brown setae; hypopygium (fig. 6) brown, with dark brown surstyli, and cream-white cerci; hypandrium broad and apically upcurved; aedeagus upcurved; ventral margin of epandrium with subequal basal and distal epandrial setae; epandrial lobe with group of short apical setae; surstylar arms overlapping and digitiform; cercus elongate, digitiform and with pale setae.

Female. - unknown.

\section{Remarks}

Acropsilus putosa is known only from the eastern highlands of Papua New Guinea. The elongate digitform cercus is diagnostic. The antenna is mostly yellow, with the first flagellomere weakly incised, and sparsely haired, and this species is close to A. albitibia.

\section{Acropsilus udotsp. n.}

(fig. 19)

Type material. - Holotype, ô Federated stATES OF MICRONESIA: Truk Group: Udot I, 25.v.1946, H.K. Townes (USNM).

Additional material. - FEDERATED STATES OF MICRONESIA: ठ, Truk Group: Moen I., Mt. Teroken N, 28.xii.1952 (BPBM)

\section{Description}

Male. - Length: 1.3; wing $0.9 \times 0.3$.

Head. - Vertex, frons dark brown with metallic green reflections; face and clypeus metallic green; palp and proboscis yellow; scape and pedicel entirely yellow; first flagellomere and arista missing.

Thorax. - Mesonotum brown with little pruinosi- 
ty; pleura matt brown.

Legs. - Coxae and remainder of legs yellow; TII with strong ad-pd pair at $1 / 4$, strong ad at $3 / 5$, and with strong ventral apical; TIII with short ad-pd pair at $1 / 4$, and short dorsal setae at $7 / 8$; IIIt $t_{1}$ globular and with some ventral setae.

Wing. - Lower calypter yellow with fan of brown setae; halter yellow.

Abdomen. - Dark brown with sparse short brown setae; hypopygium (fig. 19) brown, with dark brown surstyli, and cream-white cerci; ventral margin of epandrium with stronger basal and shorter distal epandrial setae; epandrial lobe with two apical setae, and externally overlapping digitiform surstylar arms; subepandrial sclerite broad with 3 strong, spaced apical setae; cercus expanded, elongate and spatulate, bearing weak setae.

Female. - Unknown.

\section{Remarks}

Acropsilus udot is known only from the Truk Group in the Caroline Islands. The elongate spatulate cercus is diagnostic. Although both specimens are missing the first flagellomere, based on the scape and pedicel, this species seems close to $A$. albitibia.

\section{REFERENCES}

Becker, T., 1918. Dipterologische Studien. Dolichopodidae. Dritter Teil. - Nova Acta Academiae Caesareae Leopoldino Carolinae 104: 35-214.

Bickel, D. J. \& C. E. Dyte, 1989. Family Dolichopodidae. - In: N. Evenhuis (ed.), Catalog of Australasian and Oceanian Diptera. pp. 393-418.Bishop Museum Press, Honolulu.

Bickel, D. J., 1995. Insects of Micronesia. Volume 13, no. 8. Diptera: Dolichopodidae Part I. Sciapodinae, Medeterinae and Sympycninae (part). - Micronesica 27, 73-118.

Couturier, G., 1977. Les Diptères Dolichopodidae de Côte d'Ivoire: description de trois nouvelles especès. - Bulletin de la Société entomologique de France 82: 220-225.

Cumming, J. M., B. J. Sinclair, \& D. M. Wood, 1995. Homology and phylogenetic implications of male genitalia in Diptera - Eremoneura. - Entomologica Scandinavica 26: $120-152$.
Grootaert, P. \& H. J. G. Meuffels, 1997. Griphomyia (Diptera, Dolichopodidae, Peloropeodinae), a new genus from Thailand. - Belgian Journal of Zoology 127: 107-114.

Hollis, D., 1964. Notes and descriptions of Indonesian Dolichopodidae in the Zoologisch Museum, Amsterdam. - Beaufortia 10: 239-274.

Lamb, C. G., 1922. The Percy Sladen Trust expedition to the Indian Ocean in 1905, under the leadership of Mr. J. Stanley Gardiner, M.A. Vol. 7. No. VIII. Diptera: Asilidae, Scenopinidae, Dolichopodidae, Pipunculidae, and Syrphidae. - Transactions of the Linnean Society of London (2, Zoology) 18: 361-416.

Loew, H., 1869. Beschreibung europäischer Dipteren I. Systematische Beschreibung der bekannten europäischen zweiflügeligen Insecten von Johann Wilhelm Meigen. Neunter Theil. - H. W. Schmidt, Halle. 319 pp.

Lundbeck, W., 1912. Diptera Danica, Part IV: Dolichopodidae. - S. Gad, Copenhagen. 416 pp.

McAlpine, J. F., 1981. Morphology and Terminology Adults. - In: J. F. McAlpine et al., Manual of Nearctic Diptera, Vol. 1, Research Branch Agriculture Canada, Ottawa, Monograph 27: 9-64.

Mik, J., 1878. Dipterologische Untersuchungen. - Jahresberichte der. Kaiserlich-königlichen Akademie, Gymnasium, Wien 1878: 1-24.

Negrobov, O. P., 1984. The genera of the family Dolichopodidae Diptera new for the faunas of the Palearctic and USSR. - Zoologicheskii Zhurnal 63: 1111-1115.[in Russian].

Negrobov, O. P., 1986. On the system and phylogeny of flies of the Fam. Dolichopodidae (Diptera). - Entomologicheskoye Obozreniye 65: 182-186 [English translation, Entomological Review, Washington (1987) 65: 16-20].

Parent, O., 1938. Diptères Dolichopodidae. - Faune de France 35. Paris, 720 pp.

Robinson, H., 1963. A new species of Acropsilus from the Solomon Islands (Diptera: Dolichopodidae). - Canadian Entomologist 95: 830-831.

Robinson, H. \& J. R. Vockeroth, 1981. Dolichopodidae. In: J. F. McAlpine et al., Manual of Nearctic Diptera Vol 1. - Research Branch Agriculture Canada, Ottawa, Monograph 27: 625-639.

Ulrich, H., 1981. Zur systematischen Gliederung der Dolichopodiden (Diptera). - Bonner Zoologische Beiträge 31: 385-402.

Received: 29 May 1998

Accepted: 23 June 1998 